\title{
BIODIVERSIDADE, TÉCNICA E PROPRIEDADE INTELECTUAL: ALTERNATIVAS E POSSIBILIDADES SUSTENTÁVEIS DE PROTEÇÃO
}

\author{
Francielle Benini Agne Tybusch ${ }^{1}$
}

\begin{abstract}
RESUMO
A apropriação dos saberes tradicionais por empresas e indústrias farmacêuticas e a consequente exploração da biodiversidade, revelam ser questões que buscam por alternativas capazes de promover a proteção. Este trabalho tem como objetivo buscar novas possibilidades de regulação da propriedade intelectual. Diante deste cenário questiona-se: quais as possibilidades de construir alternativas sustentáveis para a regulação da propriedade intelectual no que se refere a utilização da biodiversidade? A metodologia a ser utilizada é a sistêmico-complexa. Como método de procedimento foi empregada a análise bibliográfica e documental, e como técnica de coleta de dados optou-se pela produção de fichamentos e resumos estendidos.
\end{abstract}

Palavras-chave: Biodiversidade; Técnica; Propriedade Intelectual; Proteção; Alternativas.

\section{BIODIVERSITY, TECHNIQUE AND INTELLECTUAL PROPERTY: SUSTAINABLE ALTERNATIVES AND POSSIBILITIES OF PROTECTION}

\begin{abstract}
The appropriation of traditional knowledge by companies and pharmaceutical industries and the consequent explotation of biodiversity, are issues that seek alternatives capable of promoting protection. This work aims to seek new possibilities for the regulation of intellectual property. In view of this scenario, the question is: what are the possibilities of constructing sustainable alternatives for the regulation of intellectual property regarding the use of biodiversity? The methodology to be used is systemic-complex. As method of procedure was used the bibliographic and documentary analysis, and as data collection technique we opted for the production of extended abstracts and files.
\end{abstract}

Keywords: Biodiversity; Technique; Intelectual Property; Protection; Alternatives.

\section{INTRODUÇÃO}

\footnotetext{
${ }^{1}$ Doutoranda em Direito pela Universidade do Vale do Rio dos Sinos - UNISINOS. Mestre pela Universidade Federal de Santa Maria, no Programa de Pós-Graduação em Direito, com ênfase em Direitos Emergentes na Sociedade Global, linha de pesquisa Direitos da Sociobiodiversidade e Sustentabilidade. Possui graduação em Direito pela Faculdade Palotina de Santa Maria - FAPAS. Professora do Curso de Direito e da Especialização em Direito Civil e Processual Civil da Universidade Regional Integrada do Alto Uruguai e das MissõesURI/Santiago. Membro da equipe técnica da Revista Direitos Emergentes na Sociedade Global da Universidade Federal de Santa Maria - UFSM. Integrante do Grupo de Pesquisa em Direito da Sociobiodiversidade (GPDS) da UFSM e do Grupo de Pesquisa em Direito, Risco e Ecocomplexidade da UNISINOS. E-mail: francielleagne@gmail.com
} 
O Brasil é considerado um dos países megadiversos do mundo, por possuir a maior parcela da biodiversidade mundial. Ainda, o país também é composto por uma sociodiversidade no que se refere a comunidades indígenas, comunidades tradicionais, tais como quilombolas, ribeirinhos, dentre outros que possuem um inestimável conhecimento acerca da biodiversidade nacional.

Estas novas formas de apropriação do saber e da cultura dos povos tradicionais são denominadas por diversos autores como uma nova forma de colonialismo, ou como a segunda 'descoberta' de Colombo. Há muito tempo se questiona acerca do potencial científico, tecnológico e, consequentemente, econômico que está presente na biodiversidade. Este material tem instrumento essencial para a biotecnologia, que através deste pode criar novos produtos e serviços nas mais diversas áreas. Este potencial tecnológico presente no território brasileiro, gerou uma inquietação e, uma consequente preocupação com relação ao modo como este material está sendo retirado e utilizado pelas empresas farmacêuticas e de cosméticos.

Diante deste cenário, este trabalho tem como questionamento: quais as possibilidades de construir alternativas sustentáveis ${ }^{2}$ para a regulação da propriedade intelectual no que se refere a utilização da biodiversidade ${ }^{3}$ ?

Para responder a essa questão de pesquisa, a metodologia e estratégia de ação obedece ao trinômio: Teoria de Base; Procedimento e Técnica. O tipo de pesquisa a ser utilizada é a bibliográfica. Seu método de abordagem parte da teoria de base sistêmico-complexa (matriz teórica) na busca de percepções dialógico-dialéticas produzidas na interface entre direito, política e cultura. Como método de procedimento, na pesquisa em tela foi utilizada a análise bibliográfica e documental, bem como de legislação acerca da temática. Como técnica de coleta de dados optou-se pela produção de fichamentos e resumos estendidos.

\section{TÉCNICA E TECNOLOGIA: A biodiversidade como potencial tecnológico}

\footnotetext{
${ }^{2}$ Sustentável, pois, de acordo com Agne Tybusch (2016, p. 71): ela deve também se conectar e estar atenta para as questões sociais, econômicas, políticas, jurídicas e culturais, que seja não apenas objeto da pesquisa científica, mas possibilidade de emancipação.

${ }^{3}$ Neste artigo irá ser utilizado a expressão biotecnologia para designar os processos advindos da união entre biodiversidade e tecnologia, bem como sua aplicação na indústria farmacêutica (medicamentos).
} 
Cada vez mais os povos e a biodiversidade encontrada do Sul Social ${ }^{4}$ ficam revelados a um novo tipo de apropriação, pelo meio de novas técnicas de predação (SANTOS, 2003, p.44). E estes novos métodos, que também podem ser chamados de novas técnicas, se apresentam como meios de se apoderar da biodiversidade.

Desta forma, neste item temático abordar-se-á a questão da técnica e a importância da informação, extremamente valiosa para a indústria biotecnológica. Assim, é necessário compreender alguns conceitos que perpassam pela técnica e pela tecnologia e que, por inúmeras vezes, se apresentam como uma inversão da relação.

A teknè termo técnico advindo etimologicamente dos gregos que se explica como arte, é um conceito filosófico que almeja apresentar o saber fazer humano (LEMOS, 2002, p. 29). É o

(...) fruto de uma primeira filosofia da técnica que visa distinguir o fazer humano do fazer da natureza. A tekhnè é a arte que coloca o homem no centro do fazer poiético, em confronto direto com as coisas naturais. A tekhnè é uma poièsis no sentido de revelar todo fazer humano (GALIMBERTI, 2003, p. 02).

Os gregos acreditavam que toda a ação humana é tekhné, e na qual a técnica insere-se no registro da verdade pensada não como domínio sobre a natureza - mas como seu desocultamento, a relação do homem com a natureza era compreendida de forma imutável. Desta forma, a natureza não fazia parte da esfera pertinente à ética, pois o âmbito daquela atingia somente a regulamentação das ações humanas. Logo, não possibilitava a técnica suplantar o seu limite que permanecia inscrito no domínio dos processos naturais, e no tempo para que se configurasse como história no progressivo domínio da natureza (GALIMBERTI, 2003).

\footnotetext{
${ }^{4}$ O Sul é aqui concebido como um campo de desafios sistêmicos, que procuram reparar os danos e impactos historicamente causados pelo capitalismo na sua relação colonial com o mundo. Esta concepção do Sul sobrepõe-se em parte com o Sul geográfico, o conjunto de países e regiões do mundo que foram submetidos ao colonialismo europeu e que, com exceções como, por exemplo, da Austrália e da Nova Zelândia, não atingiram níveis de desenvolvimento econômico semelhantes ao Norte global (Europa e América do Norte). A sobreposição não é total porque, por um lado, no interior do Norte geográfico classes e grupos sociais muito vastos (trabalhadores, mulheres, indígenas, afrodescendentes, muçulmanos) foram sujeitos à dominação capitalista e colonial, e por outro lado, porque no interior do Sul geográfico houve sempre as 'pequenas Europas', pequenas elites locais que beneficiaram da dominação capitalista e colonial e que depois das independências a exerceram e continuam exercer, por suas próprias mãos, contra classes e grupos subordinados" (SANTOS; MENESES; NUNES, 2010, p. 19).
} 
Francis Bacon, em seu livro Novum Organum, indica: Conhecer para dominar. Deste modo, era conferida a ordem antropocêntrica, resultando com que o meio ambiente pudesse ser transformado em matéria passível de ser considerada fora de qualquer apreço ético.

Galimberti (2003, p. 06) aclara que o conhecimento se tornou independente em relação ao ser humano, e o poder que se encontrava no ser humano sobre a natureza passou a ser do poder da técnica sobre o ser humano e sobre a natureza. A natureza encontra-se atualmente separada da perceptibilidade e da intuibilidade da natureza, e toda a relação com ela é mediada pela própria técnica, e novamente, se quisermos protegê-la recorreremos a ela também.

Já para Heidegger a técnica era um meio de desvelamento (desocultamento) ${ }^{5}$, um modo de existência do homem no mundo, era como uma pro-vocação da natureza. O autor não se contenta com a definição de técnica como um instrumento e meio, mas se pergunta, quais são os instrumentos? Em qual contexto surgem os meios e os fins? Para Heidegger, "a técnica não é, portanto, meramente um meio. É um modo de desabrigar ${ }^{6}$. Se atentarmos para isso, abrir-se-á para nós um âmbito totalmente diferente para a essência da técnica. Trata-se do âmbito do desabrigamento, isto é, da verdade" (HEIDEGGER, 2007, p. 06).

Assim, a natureza transformava-se em um objeto, um recurso para ser utilizado pela produção técnica. $\mathrm{O}$ antropocentrismo não pode mais ser vislumbrado como o lugar no qual podem ser decididos os espaços do ser humano, pois a técnica já se despediu deste lugar há tempo, e com esta despedida o ser humano torna-se, então, um material da técnica (GALIMBERTI, 2003, p.08).

No entanto, tal modelo de concepção não estabelece limites para a técnica e para os resultados de sua ampliação sobre a natureza, ocasionando com que o uso desta produza, consequentemente, o desgaste da Terra. Deste modo, a partir da indiferença e da redução da natureza a algo que não deva ser respeitado, surge uma solução, um caminho que Hans Jonas adverte, fundamentado no princípio da responsabilidade, modificando as ações individuais em coletivas, fazendo com que a sociedade seja também responsável pela técnica.

\footnotetext{
${ }^{5}$ Para Franz Josefe Brüseke, o desocultamento (Entbergung) para Heidegger é a expressão para a sua análise da técnica moderna, pode significar tirar algo do solo e expor consequentemente à luz do sol (BRÜSEKE, 2001, p. $61)$.

${ }^{6}$ Há certa divergência na tradução da palavra Entbergung, para alguns autores significa desabrigar e para outros desocultamento. Neste trabalho, ficaremos com a tradução de Franz Josefe Brüseke que a define como desocultamento.
} 
Tal princípio se torna indispensável devido à ação do homem incidir em um atuar constantemente distanciado da natureza. Hans Jonas afirma que a técnica está solidificada e assim não se pode evitá-la, assim, a natureza modificada do ser humano começa a se preocupar com o futuro ${ }^{7}$.

Se retornarmos às ponderações estritamente inter-humanas, há ainda um outro aspecto ético no fato de que a techne, como um esforço humano, tenha ultrapassado os objetivos pragmaticamente delimitados dos tempos antigos. Àquela época, como vimos, a técnica era um tributo cobrado pela necessidade, e não o caminho para um fim escolhido para a humanidade (...) Hoje, na forma da moderna técnica, a techne transformou-se em um infinito impulso da espécie para adiante, seu empreendimento mais significativo (...) Assim, o triunfo do homo faber sobre o seu objeto externo significa, ao mesmo tempo, o seu triunfo na constituição interna do homo sapiens, do qual ele outrora costumava ser uma parte vil. Em outras palavras, mesmo desconsiderando suas obras objetivas, a tecnologia assume um significado ético por causa do lugar central que ela ocupa subjetivamente nos fins da vida humana (JONAS, 2006, p. 43).

Desta forma, sendo a tecnologia fruto da união entre a técnica e a ciência, percebe-se que não se pode separar totalmente a técnica da tecnologia. Mas algumas diferenças entre elas podem ser vistas no olhar de André Lemos sobre Simondon 2002, p. 36) que afirma que a técnica se transforma em tecnologia a partir do nível dos indivíduos técnicos. Leon Olivé sobre a tecnologia registra que

La ciencia y la tecnología son bienes públicos que pueden ser utilizados para aumentar el bienestar social y para resolver una diversidad de problemas económicos, sociales, culturales, ambientales, y de preservación de recursos. Pero también pueden ser utilizados para danar y destruir (2007, p. 38).

Beck (2010, p. 37) alega que a emergência da sociedade de risco, significa a entrada da modernidade em uma nova era de incertezas, em que a ciência e a tecnologia assumem papéis proeminentes. Portanto, toda uma cultura tecnológica alberga uma contradição latente, e também politicamente fatal. Conforme Lutzemberger (2012, p. 37-39)

Seus cidadãos, em quase sua totalidade, são analfabetos em ciência e tecnologia. Quando algo entendem, com raras exceções, são especialistas estreitos, ignorantes fora de sua especialização. Se as pessoas não entendem nem os princípios básicos da ciência e do funcionamento das tecnologias mais usadas, como vão entender as infraestruturas tecnológicas e seu alcance político, estruturas que não param de crescer e a envolver-nos de maneira sempre mais global e irreversível?

\footnotetext{
${ }^{7}$ Para isso a fundamentação do princípio responsabilidade começa com uma heurística do medo, gerando assim uma desconfiança com relação à técnica, que para Hans Jonas não tem volta. No entanto, também há a necessidade de um novo imperativo em face das éticas tradicionais não abarcarem a dimensão exigida pela civilização tecnocientífica.
} 
Lutzemberger aponta que a falácia da neutralidade ética de ciência e tecnologia procura neutralizar consciências.

Os políticos e, sobretudo, os administradores públicos, precisam entender que a tecnologia, boa ou ruim, bem ou mal intencionada, nunca é fria. Ela é sempre o resultado de emoções. A finalidade da tecnologia é atender a vontade de alguém, mexer com o mundo, dobrar vontades alheias. Portanto, a escolha da técnica é sempre um ato político, por pequeno ou grande que seja (2012, p. 43).

No mesmo sentido, Alcantára afirma que a tecnologia nunca pode ser considerada é neutra, isto é, ela se transforma no instrumento que pode fazer com que a nossa sociedade seja mais livre, mas também pode convertê-la em uma desagradável distopia que utiliza a tecnologia como forma de controle (2008, p. 25). Assim, pode-se dizer que também a ciência não é neutra,

Ela serve a grupos, a governos, a princípios e a visões de mundo. Os cientistas, sendo humanos, podem ser verdadeiros intelectuais, sensíveis, ou revolucionários, ou equivocados, ou alienados, ou ingênuos, ou tolos, ou gananciosos, ou corruptos, ou mais de uma coisa ao mesmo tempo. Mas a tecnologia, esta nunca é neutra. Serviu ao III Reich, ao comunismo, ao império romano, e serve à moderna sociedade de consumo, aos interesses financeiros de grandes empresas e corporações (MATTOS; BAPTISTA, 2011).

Vandana Shiva (2003, p. 129) corrobora e instiga outros questionamentos, no qual afirma que a ignorância sobre os impactos das novas tecnologias ${ }^{8}$ sobre o meio ambiente e a saúde humana é muito maior que o conhecimento necessário à sua produção. Assim, a ignorância e não o conhecimento caracteriza este nosso tempo.

Foram necessários 200 anos de produção baseada no combustível fóssil para os cientistas perceberem que a queima desse tipo de combustível estava tendo efeitos colaterais imprevisíveis - a desestabilização do clima, a poluição da atmosfera e a criação do efeito estufa. O DDT foi considerado a última palavra para garantir a saúde pública. Um prêmio Nobel foi a recompensa por sua invenção. Hoje sabemos que o DDT e outros pesticidas tóxicos implicam grandes custos ecológicos e de saúde e por isso, foi banido dos países industrializados. A Union Carbide instalou fábricas de produtos químicos na India, anunciando orgulhosamente que, "Temos um dedo no futuro da Índia." Este futuro incluiu a morte de 3 mil pessoas inocentes em dezembro de 1984, quando o gás MIC vazou da fábrica de pesticidas da Carbide em Bhopal (SHIVA, 2003, p. 130).

\footnotetext{
${ }^{8}$ Conforme Lutzemberger, ciência e tecnologia não são a mesma coisa. "A ciência é um valor em si. (...) A técnica aproveita-se dos conhecimentos e das informações que o diálogo limpo deu à ciência para fazer artefatos, produzir instrumentos. A técnica parte de um desejo de domínio, ela é impositiva, é o contrário da atitude básica da ciência, que é contemplativa (LUTZEMBERGER, 2012, p. 37-39, passim)
} 
Produtos e processos químicos (perigosos ou não) têm surgido em passo acelerado mais do que as estruturas de regulamentação e controle público. Ainda, ao contrário dos produtos químicos tais como os pesticidas, os produtos da engenharia genética não podem ser retirados do mercado (SHIVA. 2003, p. 130-131). Como o mercado, a economia, o direito e a política estão diante destas inovações?

Para Frijoft Capra está "nova economia" está gerando um sem número de consequências danosas e relacionadas entre si - um aumento da desigualdade e da exclusão social, um colapso da democracia, uma deterioração mais rápida e extensa do ambiente natural e uma pobreza e alienação cada vez maiores. Relata sobre diversos problemas que em decorrência de um pensamento não sustentável e de um nexo causal já não mais duvidoso entre atividade humana e aquecimento global. $\mathrm{O}$ aumento dos níveis dos oceanos, a seca, as desertificações, o aumento significativo dos desastres naturais e artificiais, a derrocada mundial dos recifes de corais.

Assim, Capra ressalta que esta globalização projetada, esta busca incessante das redes globais em atribuir um componente financeiro de cada economia acaba por levar ao pensamento (princípio básico do capitalismo selvagem) ganhar dinheiro vale mais do que a democracia, os direitos humanos, a proteção ambiental, ou qualquer outro valor. Desta forma, o autor propõe virar o jogo ${ }^{9}$, antes de mais nada mudar este princípio básico.

Os Estados mais poderosos podem na verdade utilizar a globalização como um meio de aumentar seu poder. Peter Dicken (2010, p. 196-229) cita que com o passar do tempo e sob circunstâncias históricas específicas, as sociedades desenvolveram métodos diferentes de organizar suas economias, inclusive dentro da ideologia aparentemente universal do capitalismo. Na realidade, o capitalismo tem diversos tipos, dos quais três são muito importantes: o capitalismo de mercado neoliberal; o capitalismo de mercado social; o capitalismo de desenvolvimento e agregados a este, o sistema capitalista-comunista da China. O Estados podem ser reguladores do comércio; podem ser concorrentes e colaboradores.

\footnotetext{
${ }^{9}$ A importância da sociedade civil, ONGs que se formaram em torno de valores éticos, sustentáveis e que com a ajuda das TIC, especialmente da Internet organizaram redes, trocaram informações e mobilizam membros (coalizão de Seattle - Fórum Social Mundial). O autor fala em remodelar a globalização, a mesma que deixa a homogeneidade, que agrava a pobreza, a insustentabilidade, que afoga culturas diversas através de uma descentralização do poder das instituições globais em favor de um sistema pluralista de organizações regionais e internacionais, cada uma das quais teria os seus poderes limitados por outras organizações, outros acordos e outros agrupamentos regionais (CAPRA, 2005, p. 217-66).
} 
Embora exista controvérsia sobre se os Estados se consideram ou deveriam se considerar Estados concorrentes, certamente os Estados colaboram com outros Estados para alcançar metas específicas econômicas e bem-estar social. Essas colaborações podem ser viabilizadas de várias formas dentre as inúmeras, o autor elenca e destaca uma: a tendência de os Estados desenvolverem relações político-econômicas em escala regional através de acordos de integração regional. Com relação aos tipos de integração podem ser citados: Uma área de livre comércio; Uma união aduaneira; Um mercado comum; e Uma união econômica.

Desta forma, o autor ressalta a importância do Estado como uma grande influência na economia global. O papel do Estado posição está sendo redefinida em um contexto de sistema político-econômico policêntrico, em que as fronteiras nacionais são mais permeáveis do que antigamente.

No entanto, se faz cada vez mais necessário um instrumento de proteção, principalmente quando nos referimos a medicamentos, e ainda quando estes (em sua maioria) utilizam princípios da biodiversidade. No próximo item será dissertado sobre a necessidade de regulamentação e suas possíveis alternativas.

\section{PROPRIEDADE INTELECTUAL E PATENTES: Alternativas de proteção à} biodiversidade

Em nome das ciências modernas destruíram-se muitas formas de conhecimento alternativas e humilharam-se os grupos sociais que neles se apoiavam para prosseguir as suas vias próprias e autônomas de desenvolvimento (SANTOS, MENESES; NUNES, 2005, p. 28). Assim, a concepção do outro como ausente de saber e de cultura foi o contraponto da exigência de transportar a civilização e a sabedoria para povos vivendo nas trevas da ignorância.

Assim, a natureza transformada em recurso não tem outra lógica senão a de ser explorada até a sua exaustão. Os maiores beneficiários dessa relação tem sido seguramente as indústrias farmacêuticas. No que se refere a indústria farmacêutica, é sabido que atualmente a maior parte dos medicamentos possuem substâncias retiradas da biodiversidade do Sul Social. 
Os direitos de propriedade intelectual permitem e legitimam essas formas de apropriação dos conhecimentos indígenas e locais e de apropriação privada de bens fundamentais para a salvaguarda e promoção da saúde pública assentam nas concepções privadas radicadas na ordem jurídica do capitalismo, concepção esta adotada a aplicação do Acordo sobre os Direitos de Propriedade Intelectual Relacionados ao Comércio - Trips.

Antes de adentrarmos na propriedade intelectual em si, é importante delimitarmos e conceituarmos a propriedade. Para Alejandro Knaesel Arrabal, a propriedade é um direito complexo, e cumpre entender que complexidade aqui em sentido estrido, ou seja, enquanto unidade jurídica composta por faculdades, quais sejam, o uso, a fruição e a disposição. No entanto, atualmente a propriedade incorpora o sentido de exclusividade, isto é, admitindo sua utilização sem a concorrência de outrem (ARRABAL, 2017).

Do ponto de vista jurídico, cumpre desde logo salientar as duas acepções do direito de propriedade. Num sentido amplo, este recai tanto sobre coisas corpóreas como incorpóreas. Quando recai exclusivamente sobre coisas corpóreas tem a denominação peculiar de domínio. A noção de propriedade mostra-se, destarte, mais ampla e mais compreensiva do que a de domínio. Aquela representa o gênero de que este vem a ser a espécie (MONTEIRO; PINTO, 2015, p. 99).

No século XIX, depois da Revolução Industrial, nasce o direito à propriedade intelectual. Tal direito permitia que industriais dominassem tanto sua produção, por meio da existência do sistema de patentes, como a distribuição de suas invenções, utilizando o sistema de marcas. Inexistia naquela época um sistema internacional de propriedade industrial, desta maneira, cada país possuía autonomia própria para definir a sua legislação, tal prática era falha pois, permitia que uma invenção que obtinha proteção patentária em um país pudesse ser apropriada por outro sem que isso caracterizasse uma infração (CHAVES, et al, 2007).

A primeira iniciativa de construir um sistema internacional de propriedade
intelectual ocorreu em 1883 , durante a CUP para a Proteção da Propriedade
Industrial, envolvendo 11 países, dentre eles o Brasil. Constituiu-se como União
porque representava um espaço comum de direitos entre os Estados signatários.
Vigente até os dias de hoje, ela já foi revista sete vezes. Baseia-se nos princípios da
"Independência das Patentes", do "Tratamento Igual para Nacionais e Estrangeiros"
e dos "Direitos de Prioridade"(CHAVES, et al, 2007).

Em uma Conferência Diplomática organizada em Paris no ano de 1880, a Convenção da União de Paris para proteção da propriedade industrial teve seu surgimento. Nova conferência foi convocada em 6 de março de 1883, para aceitação definitiva do texto, que entrou em vigor um mês depois do depósito de instrumentos de ratificação, em 7 de julho de 1883. O presidente da conferência de 1880 pronunciou frase histórica: "Nós escrevemos o 
prefácio de um livro que vai se abrir e que não será fechado se não após longos anos" (INPI, 2017).

\begin{abstract}
A Convenção previa em seu art. 14, "a celebração de conferências periódicas de revisão a fim de introduzir no texto original, instrumentos destinados a aperfeiçoar o sistema da união à luz da experiência obtida em sua aplicação prática". Inúmeras foram as mudanças inseridas no texto de 1883 através de 7 revisões. Na primeira, em Roma, os atos assinados não foram ratificados por nenhum país. Seguiram-se as Revisões de Bruxelas (1900), Washington (1911), Haia (1925), Londres (1934), Lisboa (1958) e Estocolmo (1967). O Brasil, país signatário original, aderiu à Revisão de Estocolmo em 1992 (INPI, 2017).
\end{abstract}

Em 1886, foi assinada a Convenção da União de Berna (CUB), que trata dos direitos do autor e referentes à proteção de obras artísticas e literárias (BRASIL, 1975). Já 1893, a CUP e a CUB uniram seus escritórios para criar o Escritório Unificado Internacional para a Proteção da Propriedade Intelectual (BIRPI). Em 1970, o BIRPI deu origem à Organização Mundial de Propriedade Intelectual (OMPI), sediada em Genebra, Suíça.

No entanto, alguns destes países que protegem um intenso sistema internacional de patentes passam a garantir proteção patentária para o setor farmacêutico apenas quando já tinham uma indústria local estruturada e com capacidade para competir no mercado internacional. Em abril de 1809, Dom João VI reconheceu a importância de uma lei de proteção intelectual para o Brasil, que foi o quarto país no mundo a criar uma lei protegendo a propriedade tanto comercial quanto industrial. Bruno Hammes afirma que só em 1875 as marcas foram regulamentadas, por meio da lei 2.682 que permitiu a qualquer indivíduo, industrial ou comerciante o direito de assinar os produtos de sua indústria ou comércio com marcas que as distinguissem (2002, p. 32).

Na Itália, por exemplo, o não reconhecimento de patentes farmacêuticas permitiu que sua indústria nacional crescesse no período pós-guerra, alcançando, inclusive, capacidade para inovar. Os Estados Unidos também se beneficiaram deste período, registrando importante avanço de sua indústria farmacêutica quando não reconheciam patentes de medicamentos, conseguiram desenvolver um programa de capacitação com base nos conhecimentos produzidos pelos alemães no período da Primeira Guerra Mundial. O Japão, por sua vez, só passou a reconhecer patentes para produtos farmacêuticos em 1976, quando já era o segundo produtor mundial do setor e tinha seu mercado interno quase todo controlado por empresas nacionais (CHAVES, 2016, p. 16). 
A OMPI perdeu importante grande parte do seu espaço de atuação, passando a fornecer assistência técnica aos países membros da OMC sobre os assuntos relacionados a este Acordo, com a entrada em vigor do Acordo TRIPS. A partir de 2001, o diretor geral da OMPI estabeleceu a "Agenda de Patente da OMPI" (Wipo Patent Agenda), cujo objetivo é criar "mecanismos e programas pelos quais inventores e indústria poderão ter acesso a sistemas efetivos de patentes em níveis nacional, regional e internacional que os favoreçam a obter, manter e implementar suas patentes globalmente" (CHAVES, 2016, p. 17).

Embora tenha perdido seu espaço de atuação, depois da criação de OMC, a OMPI lida com os aspectos práticos da ampliação do sistema internacional de propriedade intelectual e atua de forma a contribuir para o fortalecimento do modelo inicialmente desencadeado pelo Acordo TRIPS da OMC.

No ano de 1994 houve a criação da OMC e com isso o regime de proteção foi substancialmente alterado. A propriedade intelectual passou então a ser tratada como uma questão principalmente de comércio, sobrepondo-se tal interpretação à sua original função social. Ocorre que com o TRIPS, havia a ideia inicial de proteção mínima, nos termos do que define o próprio acordo em seu artigo $1^{\circ}$. Entretanto, muitos Estados, ao internalizarem a norma, concederam privilégios muito mais amplos do que aquele mínimo inicial, e "esqueceram " de cobrar algo fundamental, e em verdade, o que fundamenta a concessão de privilégios através de patentes: a contrapartida inventiva (ARRUDA; CERDEIRA, 2007, p. 120).

No entanto, a problemática reside em partes do acordo, como o artigo 33 - que define o prazo de vigência mínimo das patentes neste ramo sendo como de 20 anos. Além disso, a superproteção que se dá ao acordo traz consigo a manutenção de altos níveis de preços, bem como de lucros vultosos, pois parece que ao fim e ao cabo não há uma defesa contra a proteção mais ampla que a exigida pelo próprio acordo, o que é extremamente perigoso para países que não se encontram no polo hegemônico do poder mundial, pois estes nada ganham com o fortalecimento da indústria farmacêutica.

Não se nega a utilidade, dinamismo e inovação criada com as patentes sem e tratando do caso específico. Entretanto, o que não pode existir é o demasiado peso de um lado da balança possibilitando que as patentes tenham demasiada força e sirvam aos seus senhores, deixando em detrimento à população de um modo geral. 
[...] as patentes industriais atuam como poderosas estratégias tecnológicas que garantem aos países centrais posições privilegiadas como detentores da capacidade de produzir bens e serviços, produzindo também a dependência tecnológica dos países periféricos, funcionando como mecanismos de reserva de mercado, distanciando-se cada vez mais de suas origens de retribuição pública ao esforço intelectual individual por benefícios prestados à sociedade (PRONER, 2007).

Ora, aqui o tema é a questão dos medicamentos, mas o imbróglio vai para muito além disso. A atuação como eternos colonizados não nos traz independência alguma dos mesmos senhores de sempre. Aliás, mudam-se os atores - dominantes e dominados - mas, jamais o romance ensejador do livro.

A questão aqui, em verdade, é muito mais velada do que se parece, se utiliza uma verdadeira cortina de fumaça, lacunas onde permeiam fatos, mas sem transparência alguma. Isso se dá, principalmente, atacando em duas frentes:

a) as utilizações de métodos de internalização de algo através de ideias travestidas de instrumento de relações externas entre países, como os tratados de cooperações técnicas, por exemplo, os quais, frequentemente são danosos para os interesses de nações em desenvolvimento, principalmente quando a relação de poder hegemônico apresenta-se em total desequilíbrio, cabe ressaltar que referindo-se ao tema das patentes de medicamentos, os EUA vêm negociando uma série de acordos comerciais bilaterais ou regionais com vistas a enfraquecer ou, até mesmo, anular os efeitos da Declaração de Doha sobre Saúde Pública, que institui garantias aos países periféricos; b) a apropriação de conhecimentos já obtidos por povos locais, os quais podem ser alcançados por processos químicos simples, uma vez que o extrato ensejador do medicamento ( ou algo parecido) já está separado pela população local (PRONER, 2007).

A prática do colonialismo, aqui definida como apropriação de territórios e seres (de modo geral), parece ainda estar ocorrendo, contudo, com novas facetas e mecanismos políticos mais sofisticados. A apropriação de formas de vida (em um sentido genérico) ainda, de alguma forma, se realiza nos dias de hoje, incorporando "novos selvagens" (termo clássico do colonialismo/cristianismo em seu processo de dominação).

Quinhentos anos depois de Colombo, uma versão secular do mesmo projeto de colonização está em andamento por meio das patentes e dos direitos de propriedade intelectual (DPI). [...] A vacância das terras foi substituída pela vacância de vida e espécies, modificadas pelas novas biotecnologias. O dever de incorporar selvagens ao cristianismo foi substituído pelo dever de incorporar economias locais e nacionais ao mercado global, e incorporar os sistemas não-ocidentais de conhecimento ao reducionismo da ciência e da tecnologia mercantilizada do mundo ocidental (SHIVA, 2001, p. 24).

A autora reflete sobre a ideia do processo de colonização como um precedente, e isto fica evidente com o seguinte comentário: 
A liberdade que as empresas transnacionais estão reivindicando por meio da proteção aos DPI, no acordo GATT sobre os Direitos de Propriedade Intelectual Relacionados ao Comércio (TRIPS), é a liberdade que os colonizadores europeus usufruíram a partir de 1492. Colombo estabeleceu um precedente quando tratou a licença para conquistar povos não-europeus como um direito natural dos europeus (SHIVA, 2001, p. 24).

Então, o ponto central que parece sobressair desta análise é que o mesmo processo de colonização que, de sua forma, negava a humanidade dos povos colonizados, ocorre, atualmente, pelas políticas que regulamentam o tema contemporaneamente. Trata-se de uma atualização da apropriação "natural" que definia "o povo colonizado como parte da natureza", negando sua autonomia.

A versão atualizada deste processo de dominação, segundo os argumentos da autora, se dá da seguinte forma:

\begin{abstract}
[...] apenas os detentores de capital têm o direito natural de possuir recursos naturais, e este revoga os direitos comuns de outras pessoas, anteriormente estabelecidos. O capital é, dessa forma, definido como uma fonte de liberdade que, ao mesmo tempo, nega a liberdade à terra, às florestas, aos rios e à biodiversidade, que o capital reivindica como seus, e a outros seres humanos cujos direitos se baseiam no seu trabalho. A devolução da propriedade privada ao povo é vista como expropriação da liberdade dos detentores do capital. [...] Essas noções eurocêntricas de propriedade e pirataria são as bases sobre as quais as leis de PDI do GATT e da Organização Mundial do Comércio (OMC) foram formuladas (SHIVA, 2001, p. 25).
\end{abstract}

Parece haver, pelos os indícios que a autora nos dá, de ainda temos, portanto, um impulso colonizador na relação descoberta/conquista. Trata-se de uma impressão secular na formação de nossa cultura, cujo cerne, ainda, é a negação de uma autonomia (humanidade), ora anulada por isso que a autora denomina de uma "segunda chegada de Colombo".

Na sequência dessa conquista por meio da naturalização, a biodiversidade é definida como natureza - as contribuições culturais e intelectuais dos sistemas de conhecimento não-ocidentais são sistematicamente apagadas. [...] Os conflitos desencadeados pelo tratado do GATT, pelo patenteamento de forma de vida e de conhecimentos indígenas e pela engenharia genética estão assentados em processos que podem ser resumidos e simbolizados como a segunda chegada de Colombo (SHIVA, 2001, p. 26).

Pelos argumentos expostos pela autora, a "descoberta" de Colombo e seu tratamento da pirataria como um direito natural do colonizador, se realiza hoje, em relação ao GATT (suas leis e patentes), no tratamento da biopirataria como um direito natural das grandes empresas ocidentais.

Há forte discussão sobre a apropriação/patenteamento de formas de vida, sejam elas naturais, sem a intervenção humana, ou modificadas/alteradas, através de processos 
sofisticados da genética e de outras ciências aplicadas. Em que pese ser forte a resistência quanto a apropriação de formas de vida que entendemos como naturais (não interferidas), as discussões giram em torno da definição do próprio conceito de biodiversidade ${ }^{10}$, no que trata a possibilidade, portanto, de sua apropriação.

A grande controvérsia que se levanta na discussão, portanto, tem dois pontos aparentemente bem definidos. Por um lado, os interessados na patente definem que sua criação é inédita, ou seja, inexistente na natureza. Por outro lado, aqueles que combatem esta prática, alegam que os cientistas não criam tais formas de vida, apenas interferem na estrutura genética de organismos vivos pré-existentes.

Este problema "conceitual" se torna central para a discussão quando se faz necessário apontar responsabilidades do "criador" sobre a "criatura". E a autora aponta isto como um ponto de incoerência, já que:

Quando os direitos de propriedade para formas de vida são reivindicados, isto se faz sob a alegação de que elas são novas, inéditas e inexistentes na natureza. Entretanto, quando chega o momento de os 'proprietários' assumirem a responsabilidade pelas consequências de liberar no meio ambiente organismos geneticamente modificados (OGM), de repente, as formas de vida deixam de ser novas. Elas são naturais e, portanto, seguras, sendo a questão da biossegurança tratada como improcedente (SHIVA, 2001, p. 45).

A discussão sobre o apropriável em termos de produção de vida assume contornos complexos, em decorrência tanto de interesses econômicos na possibilidade de patente, quanto na preservação da via e sua responsabilidade por ela. Para não entrar nas miudezas desse embate de berlindas, a posição da autora, efetivamente, é a seguinte:

Patentear seres vivos estimula dois tipos de violência. Primeiro, formas vivas são tratadas como se não passassem de máquinas, negando-lhes assim sua capacidade de auto-organização. Segundo, ao permitir o patenteamento de futuras gerações de plantas e animais, nega-se aos seres vivos a capacidade de auto-reprodução (SHIVA, 2001, p. 46).

O principal argumento que a autora coloca é que "os seres vivos, ao contrário das máquinas, se auto organizam. Devido a esta propriedade, eles não podem ser tratados como simplesmente ‘invenções biotecnológicas', ‘construtos genéticos', ou 'produtos da mente' que precisam ser protegidos como 'propriedade intelectual (SHIVA, 2001, p. 46). Assim, trata-se

${ }^{10}$ A biodiversidade foi redefinida como 'invenções biotecnológicas', para tornar o patenteamento de forma de vida aparentemente menos controvertido. Essas patentes são válidas por 20 anos e, portanto, cobrem gerações de plantas e animais. No entanto, mesmo quando cientistas em universidades embaralham genes, eles não 'criam' o organismo que a seguir patenteiam (SHIVA, 2001, p. 42). 
de uma marca reducionista da ciência: "o paradigma da construção na biotecnologia baseia-se no pressuposto de que a vida pode ser construída. As patentes de seres vivos baseiam-se no pressuposto de que a vida pode ser objeto de posse porque foi construída”.

A possibilidade de intervenção nos processos biológicos de formação da vida, bem como a vida a possibilidade de apropriação da vida como propriedade abre, para economia, novos horizontes, e em um nível global. Não se trata apenas de situações mais ou menos setorizadas, mas de um interesse global, mesmo que em oposição crítica a esta postura. Os comentários a seguir estão fundados nos argumentos de Jeremy Rifkin sobre o tema:

\footnotetext{
No cerne do problema do que pode ser patenteado fica a questão de se decidir se genes, células, tecidos, órgãos e organismos construídos são realmente invenções humanas ou meros achados da natureza que foram habilidosamente modificados por seres humanos (1999, p. 47).
}

Rifkin coloca a questão como uma lógica forçada, pelos seguintes argumentos:

\begin{abstract}
Condições para a patente:
[...] Para concessão da patente, o inventor deve provar que o objeto de sua solicitação é original, não óbvio e útil - em outras palavras, que seja novo, que não seja uma decorrência evidente do estado da técnica anterior, acessível a qualquer técnico da especialidade, e que tenha uma finalidade útil.

- oposição ao padrão de concessão de patente: [...] Contra esse padrão, existe um requisito igualmente compulsório: se algo é novo, não óbvio e útil, e é uma descoberta da natureza, então não é uma invenção e, portanto, não é patenteável.

[...] Nenhuma pessoa sensata ousaria sugerir que um cientista que isolou, classificou e descreveu as propriedades do hidrogênio, do hélio ou do oxigênio deveria conseguir o direito exclusivo, por vinte anos, de definir essas substâncias como invenção humana. [...] A lógica que prevaleceu torna-se ainda mais forçada, quando se pensa na patente de uma linhagem celular, em um órgão geneticamente modificado ou em um animal inteiro (1999, p. 47-48).
\end{abstract}

Um dos argumentos que o autor supracitado combate é de que, por haver um processo de invenção, isto concederia ao inventor a possibilidade da patente, pela lógica normativa que regula o tema. Ocorre que, segundo Rifkin, "nenhum dos genes, células, tecidos, órgãos e organismos para os quais estão solicitando patente foi montado ou fabricado" (RIFKIN, 1999, p. 48).

Esta situação conflitante, entre a possibilidade e a impossibilidade de patenteamento de formas de vida cria uma disputa sem precedentes entre as empresas do setor químico, farmacêutico, agrícola e biotecnológico para a obtenção de patente comercial. E esta guerra de berlinda, comumente importa em complexas e vultosas discussões judiciais. 
[...] Enquanto os recursos tecnológicos necessários para manipular o novo 'ouro verde' encontram-se nos laboratórios e nas salas de diretoria do Hemisfério Norte, a maior parte dos recursos genéticos essenciais para alimentar a nova revolução encontra-se nos ecossistemas tropicais do Hemisfério Sul. A batalha entre empresas multinacionais do Norte e os países do Sul pelo controle sobre os domínios genéticos do planeta parece ser uma das principais disputas econômicas e políticas do século biotecnológico (RIFKIN, 1999, p. 51).

Com isso o embate entre meio ambiente, indústria e governo se faz presente. De que modo inovar, desenvolver economicamente sem prejudicar os interesses da ética e dos direitos humanos. A resposta poderia vir com a hélice quadrupla, proposta por Wilson Engelmann (2010). A proposta fundamental do autor é a "hélice quádrupla", ou seja, utiliza a base da hélice tríplice de Henry Etzkowitz (2009) ${ }^{11}$, com a interação entre universidade, empresa e governo (o autor prefere utilizar Estado ao invés de governo sob a premissa que aquele é mais abrangente e duradouro) e acrescenta uma quarta hélice, qual seja: os Direitos Humanos. Segundo o autor, a nova célula seria responsável pela conformação ética da capitalização do conhecimento.

Outra alternativa proposta por Engelmann (2015) é a pluralidade de fontes, já que a legislação não alcança todas as possibilidades. "A lei demonstra ser incapaz de prever todos os casos concretos, no entanto, as situações não previstas seguem exigindo posições e soluções do jurídico. Um dos desafios é aprender a pluralidade das fontes, vencendo o reducionismo codificador".

Ainda, outra possibilidade seria a criação de um banco de dados em que houvesse a catalogação destes conhecimentos, para tentar evitar os casos de biopirataria. O Novo Marco Legal da Biodiversidade nos traz a ideia de um banco de dados.

A nova lei foi sancionada em 20 de maio de 2015, e define patrimônio genético como “informação de origem genética de espécies vegetais, animais, microbianas, ou espécies de outra natureza, incluindo substâncias oriundas do metabolismo destes seres vivos". O texto modifica a forma de solicitar autorização para explorar a biodiversidade. Anteriormente, as empresas submetiam uma documentação ao Conselho de Gestão do Patrimônio Genético (CGen) e aguardavam a aprovação para iniciar os trabalhos. Com a nova legislação, organizações nacionais poderão fazer cadastro simplificado pela internet.

\footnotetext{
${ }^{11}$ Henry faz uma abordagem acerca da hélice tríplice, ou seja, trabalha a interação entre universidade, indústria e governo como ponto fundamental para a inovação e o desenvolvimento econômico e social. Acredita que a utilização do formato da hélice tríplice em uma sociedade civil próspera tenderia ao incentivo e surgimento de variadas fontes de inovação. Com efeito, o resultado surge a partir da união das ideias e das técnicas de dinâmica dos grupos (ETZKOWITZ, 2009).
} 
A ideia basilar da nova lei é alterar a obrigatoriedade atual de autorizações para essas pesquisas com recursos genéticos nativos do Brasil por um cadastro administrado pelo governo para o controle de empresas que realizem esse acesso. Além, de cobrar royalties apenas quando há desenvolvimento a partir dos recursos genéticos.

A lei 13.123, de 20 de maio de 2015 em seu capítulo II trata sobre as competências e atribuições do Conselho de Gestão do Patrimônio Genético (CGen) que deverá criar um banco de dados que

$\mathrm{X}$ - criar e manter base de dados relativos:

a) aos cadastros de acesso ao patrimônio genético ou ao conhecimento tradicional associado e de remessa;

b) às autorizações de acesso ao patrimônio genético ou ao conhecimento tradicional associado e de remessa;

c) aos instrumentos e termos de transferência de material;

d) às coleções ex situ das instituições credenciadas que contenham amostras de patrimônio genético;

e) às notificações de produto acabado ou material reprodutivo;

f) aos acordos de repartição de benefícios;

g) aos atestados de regularidade de acesso;

$\mathrm{X}$ - cientificar órgãos federais de proteção dos direitos de populações indígenas e comunidades tradicionais sobre o registro em cadastro de (grifo nosso) .

Parte-se do pressuposto de que estes bancos realmente pudessem ser públicos e evitassem a biopirataria, isto é, não poderiam ficar nas mãos dos detentores econômicos, mas sim dos detentores deste saber tradicional, já que é inevitável que haja o desejo de exploração por parte dos "países do Norte". Por isso, urge a necessidade de um regime jurídico diferenciado, que possa proteger estes conhecimentos que também são formados de forma diferenciada.

Para Juliana Santili e Vinícius Garcia Vieira é necessária a criação de um regime sui generis. Juliana Santili, afirma que para a proteção dos conhecimentos tradicionais associados, a criação do regime deve-se pautar nas concepções do pluralismo jurídico e no reconhecimento da diversidade jurídica existente nas sociedades tradicionais, expressão de sua diversidade cultural.

Já Vinícius Vieira, propõe uma alternativa de proteção diferenciada, um regime sui generis latino-americano que protegesse os saberes tradicionais na categoria de direitos congênitos possui capacidade de contraposição ao regime internacional de propriedade intelectual, à medida que coloca os direitos dos povos tradicionais em estandartes jurídicos 
que não se subsumem à lógica dos direitos individualista liberal que fundamentam os direitos de propriedade intelectual .

Carol Proner sobre a reivindicação do direito à biodiversidade parece responder a essa demanda por superação de limites, instigando questionamentos para além das respostas possíveis dentro do atual sistema ultraliberal (respostas sistêmicas). A biodiversidade questiona, ao mesmo tempo, o equilíbrio ambiental, social, animal, populacional, cultural, sustentável em todos os tempos, unindo passado, presente e futuro (gerações futuras). Por conta desse potencial argumentativo e emancipatório, sua afirmação como direito humano encontra resistências de primeira ordem no contexto da globalização econômica

Apesar de existirem alternativas para a proteção destes conhecimentos e saberes tradicionais, nenhuma das ideias apresentadas pelos autores aconteceu concretamente, pelo contrário, no final de 2014 entrou em vigor o Protocolo de Nagoia (ainda não ratificado pelo Brasil), isto é, perderá a oportunidade de debater e definir as regras de acesso e repartição de benefícios. Corroborando, de certa forma, com uma legislação vinculada ao caráter de mercadorização da biodiversidade e meio ambiente.

A resposta a esta situação de uma crise de proteção aos conhecimentos e saberes tradicionais passa por um duplo processo de debate interno no próprio campo da ciência e de abertura de um diálogo entre formas de conhecimento e de saber que permita a emergência destes saberes tradicionais, e que estes possam dialogar e articular-se com outras formas de saber (tanto o tradicional quanto o científico) evitando a desqualificação mútua e procurando novas configurações de conhecimentos.

\section{CONCLUSÃO}

O trabalho teve como questionamento, refletir sobre quais os limites e possibilidades de alternativas sustentáveis para a regulação da propriedade intelectual no que se refere a utilização da biodiversidade? Para responder ao questionamento, dois itens temáticos foram construídos. O primeiro dissertando sobre a técnica e o segundo sobre a propriedade intelectual e patentes. Verificou-se que regulações existem, no entanto, as medidas encontradas no Acordo Trips (como nas outras regulamentações) sobrepõem-se os interesses econômicos, mostrando-se permissivas e atendendo aos interesses dos setores produtivos, ao mesmo tempo em que não apresentam medidas e políticas públicas. 
Durante muito tempo se questionou sobre o potencial científico, tecnológico e, por conseguinte, econômico, que está presente na biodiversidade. Esta é matéria prima essencial para a criação de novos processos, novos produtos e serviços nas mais diversas áreas. No entanto, tal potencial gerou certa preocupação em como o mesmo é utilizado/patenteado e retirado pelas empresas farmacêuticas, por exemplo.

A temática da propriedade intelectual não é nova, a ideia de descobrir, inovar e tomar algo como seu, conforme visto anteriormente, é muito antiga. No entanto quando confrontada com setores econômicos e políticos deve se ter cuidado para a hélice não ser somente tripla, mas quádrupla, e inserir os direitos humanos.

Assim, o direito ou a norma na atualidade não possui condições de acompanhar a velocidade da produção de novidades tecnológicas e o diálogo entre as fontes passa a ser uma extraordinária opção de geração do Direito, onde os marcos normativos e as respostas jurídicas criadas deverão considerar a contribuição de cada uma das fontes apontando sempre à proteção dos seres humanos e do meio ambiente.

Ou seja, é necessário reconhecer a existência de outras culturas. Deve existir uma política passa que perpasse pela aposta de uma interculturalidade que permita reconhecer as diferenças culturais e de conhecimento, e permita este direito de ser diferente. Pois, os meios e alternativas de proteção que se encontram em vigência, atualmente, não consideram a diferença e a existência de diferentes culturas e saberes. Por isso, é necessário pensar em alternativas para a proteção destes conhecimentos e saberes tradicionais, que não estejam mais atrelados e vinculados ao caráter de mercadorização da biodiversidade e meio ambiente, tais como os bancos de dados apresentados pela nova lei de biodiversidade.

\section{REFERÊNCIAS}

AGNE TYBUSCH, Francielle Benini. Biodiversidade, Tecnologia e Sociedade: O Direito à informação ambiental sustentável como possibilidade emancipatória na proteção dos conhecimentos tradicionais. Dissertação - Universidade Federal de Santa Maria, 2016.

ALCANTÁRA, José F. La sociedad del control: privacidad, propiedad intelectual, y el futuro de la liberdad. Barcelona: Ediciones El Cobre, 2008. 
ARRABAL, Alejandro Knaesel. Propriedade intelectual e inovação: ressignificações a partir do pensamento complexo de Edgar Morin. Tese de Doutorado. Programa de PósGraduação em Direito, Universidade do Vale do Rio dos Sinos, São Leopoldo, 2017.

BACON, Francis. Novum Organum. Disponível em: http://www.psb40.org.br/bib/b12.pdf Acesso em: 12 de jan. de 2018.

BRASIL. DECRETO No 75.699, DE 6 DE MAIO DE 1975. Disponível em: http://www.planalto.gov.br/ccivil_03/decreto/1970-1979/d75699.htm Acesso em: 11 de jan. de 2018.

BECK, Ulrich. Sociedade de Risco: Rumo a uma outra modernidade. Trad. Sebastião Nascimento. São Paulo: Ed. 34, 2010.

BRÜSEKE, Franz J. A técnica e os riscos da modernidade. Florianópolis: Editora da UFSC, 2001.

CAPRA, Fritjof. Virando o jogo. IN: As Conexões Ocultas: Ciência para uma vida sustentável. Tradução de Marcelo Brandão Cipolla. São Paulo: Cultrix, 2005.

CHAVES, Gabriela Costa. Patentes farmacêuticas: por que dificultam o acesso a medicamentos? Organizadores Renata Reis, et al. Rio de Janeiro: ABIA, 2006.

CHAVES, Gabriela Costa; OLIVEIRA, Maria Auxiliadora; HASENCLEVER, Lia; MELO, Luiz Martins de. A evolução do sistema internacional de propriedade intelectual: proteção patentária para o setor farmacêutico e acesso a medicamentos. In: Caderno de Saúde Pública vol.23 no.2 Rio de Janeiro Feb. 2007. Disponível em: Acesso em: 09 de jan. de 2018.

DICKEN, Peter. “O Estado está morto ... Vida longa ao Estado.” In: Mudança Global: mapeando as novas fronteiras da economia mundial. Tradução de Teresa Cristina Felix de Sousa. 5. ed. Porto Alegre: Bookman, 2010.

ENGELMANN, Wilson. As nanotecnologias e a Inovação Tecnológica: a "hélice quádrupla" e os Direitos Humanos. In: Nanotecnologias: um desafio para o Século XXI, 2010, São Leopoldo. Anais do Seminário. São Leopoldo : Editora Casa Leiria, 2010a. v. 1CD.

ENGELMANN, Wilson; VON Hohendorff, Raquel; SANTOS, Paulo Junior Trindade dos. A Inovação nanotecnológica e suas consequências nas Ciências de Impacto: A necessária 
inovação e adaptação do Direito para dar respostas jurídicas adequadas In: III Semana de Ciência Política Universidade Federal de São Carlos - 27 a 29 de abril de 2015.

ETZKOWITZ, Henry. Hélice Tríplice: Universidade - Indústria-Governo: Inovação em Movimento. Tradução de Cristina Hintz. Porto Alegre: EDIPUCRS, 2009.

GALIMBERTI, U. Psiche e techne. L'uomo nell'età della técnica. 2.ed. Milano, Feltrinelli, 2003. Parte VI, cap. 45, PP. 474-487. Trad. Portuguesa de Selvino J. Assmann.

HAMMES, Bruno. O Direito de Propriedade Intelectual. São Leopoldo. Ed. Unisinos, 2002 , p. 32.

HEIDEGGER, Martin. A questão da técnica. Scientiæ zudia. São Paulo, v. 5, n. 3, p. 375-98, 2007.

INPI. Convenção de Paris. Disponível em: http://www.inpi.gov.br/legislacao-1/cup.pdf Acesso em: 11 de jul de 2017.

JONAS, Hans. Princípio Responsabilidade: ensaio de uma ética para a civilização tecnológica. Trad.Marijane Lisboa \& Luis Barros Montez. Rio de Janeiro: Contraponto EDPUC-RJ, 2006.

LEMOS, André. Cibercultura: Tecnologia e vida social na cultura contemporânea. Porto Alegre: Editora Sulina, 2002.

MATTOS, Ruben Araujo; BAPTISTA, Tatiana Wargas de Faria. Caminhos para Análise das Políticas de Saúde. Disponível em: http://www.ims.uerj.br/ccaps/wpcontent/uploads/2011/10/LivroCompleto-versao-online.pdf Acesso em: 10 de jan. de 2018.

MONTEIRO, Washington de Barros; PINTO, Ana Cristina de Barros Monteiro França. Curso de Direito Civil: Direito das Coisas. São Paulo: Saraiva, 2015.

PRONER, Carol. Propriedade intelectual: para uma outra ordem jurídica possível. São Paulo: $\quad 2007 . \quad$ Cortez, Disponível em: <http://bibliotecavirtual.clacso.org.ar/ar/libros/varios/Proner_2007.pdf> Acesso em: 12 de jan. de 2018.

RIFKIN, Jeremy. O século da biotecnologia. São Paulo: Makron Boocks, 1999. 
SANTILI, Juliana. Conhecimentos tradicionais associados à biodiversidade: elementos para a construção de um regime jurídico sui generis de proteção. In: PLATIAU, Ana Flávia Barros; VARELLA, Marcello Dias (Orgs.). Diversidade biológica e conhecimentos tradicionais. Belo Horizonte, MG: Del Rey, 2004.

SANTILI, Juliana. Socioambientalismo e Novos Direitos: Proteção Jurídica à diversidade biológica e cultural. São Paulo: Peirópolis, 2005.

SANTOS, Boaventura de Sousa; MENESES, Maria Paula G. de; NUNES, João Arriscado. Introdução: Para ampliar o cânone da ciência: a diversidade epistemológica do mundo. In: SANTOS, Boa Ventura de (org.). Semear outras soluções: os caminhos da biodiversidade e dos conhecimentos tradicionais. Rio de Janeiro: Civilização Brasileira, 2005.

SANTOS, Laymert Garcia dos. Politizar as novas tecnologias: O impacto sócio-técnico da informação digital e genética. São Paulo: Ed. 34, 2003.

SHIVA, Vandana. Biopirataria: a pilhagem da natureza e do conhecimento. Petrópolis: Vozes, 2001.

SHIVA, Vandana. Monoculturas da Mente: perspectivas da biodiversidade e da biotecnologia. São Paulo: Gaia, 2003.

VIEIRA, Vinícius Garcia. Direito da Biodiversidade e América Latina: A questão da Propriedade Intelectual. Ijuí: Editora Unijuí, 2012. 